\title{
東北地方における郷士集落について* (1)
}

\section{長 井 政 太 郎}

\section{東北の郷士制}

郷士とは武士にして農村に居住し，または農民にして武士の待遇を受け ていたものをいうが1，実際は農民に大れるべきか，郷士とすべきか判然 としない中間のものが少なくない。伊達藩の品変り百姓と呼ばれるものの ごときはその好例で2，農閑期に武芸を練つていたものが，境警戒の任務 を与えられていたのみで軍役はなく，特別の軍務を命ぜられた場合のみ， 苗字帯刀を許されることになつていた. 彼等は元文 4 年(1739)の外国船警 戒の際や，伊達騒動の折も動員され戊辰戦争（1891）にも参加しているか ら，献金によつて武士の待遇を受けた水戸藩 3 ） ・ 米沢藩・仙台藩等の非戦 闘員と称すべき郷士との区別は明らかでない，彼等は白石城攻撃に参加し て，政宗に手柄を賞せられ，苗字帯刀を許され，「後世共に御弓箭の節は 御奉行仕る可き旨仰世付置かれ」4)た者共であつたが，寬文年間（1661〜 1672)より苗字带刀鞍馬等を差留められたのであつた。

三面5)の小池家は平家の落武者であるとの口碑を伝え，三面一円 140 石 余を支配していたが，元和 3 年（1617）村上城主堀丹後守より知行百石の 折紙を鿓つてから 100 石となり，本多能登守の時代，知行を召上げられ， 境守として 5 石の切米を給せられたと, 新保組大庄屋から村上藩に報告し た控書等が残つている土豪である. 正德 6 年 (1716) の縁定覚によると， 小国の御役屋附きの侍丹家等との婚姻が行われて来た家柄であるが，椎葉 村の地頭等と比較すべきものらしい.

* 此の研究は 1954 年，55 年の筆者に対する文部省科学研究費によつて研究したも ので，主として，筆者の分担した部分の概要である.

1）小野武夫 : 郷士制度の研究，大正 14 年:

2）邚田郡誌：昭和 3 年.

3）瀬谷義彦 : 水戸藩における郷士制度の史的考察 茨城大学文理学部紀要 人文 科学 第 1 号 1951 .

4) 刏田郡誌. 前揭.

5）抵稿 同族集落大倉と三面 山形大学地理学研究，第 1 号 昭和 30 年. 
米沢藩6) では約 6,000 戸の直臣の内, 2,000 戸を南原・花沢等の城外の 原野地と玉庭盆地等に配置して，半農生活を続けさせていたが，小国・中 山・荒砥・鮎貝・高皇等の要地には, 御役屋と呼ばれる支城付きの屯田兵 を配置して民政を分担させていた。

この外䆶田村の色部家中のごとき，山口新地の中条家虫，鮎貝の本庄家 中のごとき大身者の陪臣を屯田させていた部落もあつたが，最も大きい寉 田が 124 戸程度に過ぎず，仙台藩の陪臣集落ほど大規模ではなかつた。

直江兼続の最上攻略戦に参加した伊達・湮生の遺臣で, 地方に土着して いた土豪の多くは，譜代の者とともに土着して農耕を続け，100 石を給せ られたが7，大部分は領地が四分一になつた折禄を失い，税の一部を免除 される馬上御危のいわゆる免許百姓となつたが，その株は由緒による相続 という名目で売買されている. 彼等も大阪陣や島原乱に動員を命ぜられ， 譜代の者とともに出動した記録が見える.

庄内の酒井家でも，武藤や最上の遺臣で土着していた土豪に，100石の 禄を与えて大庄屋・大組頭等に登用している8). 文久 3 年 (1863) 頃外国 船に備えて，30 戸の警備隊を飯盛山下に配置し9)，その生活の便宜に備え る目的で, 13 戸の農民部落を設けさせたが10)，廃藩とともに警備隊は鶴岡 に引揚げたので，農民の部落だけ残つている.

秋田藩でも角館・六郷等に守備隊に類する武士の集団を配置していた ${ }^{11) . ~}$ その数は多くなく, 天神堂の藤井家のごとく, 500 石の郷士として登用さ れた土豪も見えるが，これまたその数は僅少であつた.

東北地方は四国・九州と同㥞に外様の大藩が残つたので，一国一城制が 徹底せず, 兵農分離も完全に行われず, 半農半兵の鄉士制が続けられた薩 摩藩 ${ }^{12}$ ・土佐藩・佐賀藩等に比較すべき仙台藩・相馬藩・米沢藩があつた. この内. 米沢藩に関するものは先に報告したことがある13)ので, 仙台藩と

6) 拙稿 米沢藩の郷士聚落の研究 山形罧郷土研究会 郷土研究叢書 第 6 輯. 昭和 11 年.

7）赤湯町石岡与市氏所蔵 苗字带刀兔許百姓面附之覚.

8）長井所蔵. 庄内大庄屋伝.

9）酒田市坂野辺新田佐藤久蔵氏所藏 古図ならびに記録類.

10) 拙稿 坂野辺新田の発達、昭和 30 年.

11）拙稿 横手盆地の集落 人文地理 7,5 昭和 30 年.

12）太田喜久雄：薩藩領麓の研究地球 15，5，6 昭和 31 年.

伊藤美年 : 麓集落 現代地理講座 4 . 昭和 31 年.

13）芳賀善次郎の「長井盆地開拓の歴史地理的考察と今後の問題」新地理 2,5 に 筆者の（6）の概要記載あり. 
相馬藩の郷士制度と集落について概要を報告しておきたい。

\section{相馬藩の郷士制度とその集落}

相馬家は鎌倉時代からの地頭として勢力のあつた家であるが，慶長 7 年 (1602）知行召上となつた14). この時，主家を見捨てたものがあつたので, 間もなく 5 万石の領地を与えられて復活 を許された折，30 名を断絶し，500 名 の知行を没収してしまつた. 同 16 年 （1611）中村を居城とし，泉城を隠居城 と定め, 28 石以上の高禄者の城下移住を 命じたが，その数は 212 名を数光，在郷 にそのまま残つた者が 880 名程あつた。

「三郡役騎相定事」15)には文禄頃は騎馬 武者 710 騎, 歩卒 3,950 とあるのに比較 すると，大部減つているわけである。 212 名の城下に集められた高給武士の知 行は全石高の $57 \%$ を占め, その上在郷 居住者が居つたのであるから，藩庫の収 入は少なく，100石に付き 3 両 1 歩の定 役を徵集せざるを得なかつた。元和 3 年 （1617）にはその上， 2 両 2 歩の増徵を 必要とする状態に陥つたのであるが，10

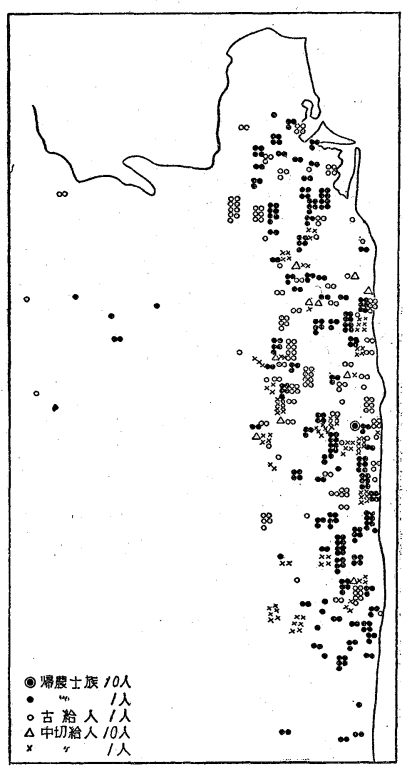

相馬藩郷士の分布図

第 1 表 相馬藩の郷士（相馬藩政史による）

\begin{tabular}{|c|c|c|c|c|c|c|c|c|c|c|}
\hline & & 文祿 2 年 & 元和 3 年 & 㺺永16年 & 明糜 4 年 & 安永年間 & 交政 5 年 & 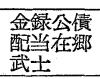 & $\begin{array}{l}\text { 㾮下住家中 } \\
\end{array}$ & 合計 \\
\hline 宇 多 & 鄉 $\left\{\begin{array}{l}\text { 南方方 } \\
\text { 等 }\end{array}\right.$ & $\begin{array}{ll}\text { 方 } & 27 \\
2\end{array}$ & 113 & 123 & $\left\{\begin{array}{l}\text { 南方23 } \\
\text { 方 } 27\end{array}\right.$ & 386 & 287 & 387 & 127 & 514 \\
\hline 北 & 郷 & 46 & 49 & 49 & 46 & 269 & 267 & 269 & 46 & 315 \\
\hline 中 & 郷 & 71 & 80 & 79 & 71 & 384 & 443 & 384 & 134 & 518 \\
\hline 小 高 & 郷 & 129 & 46 & 46 & 129 & 129 & 343 & 123 & 83 & 206 \\
\hline 北標葉 & 郷 & & & & & 108 & & 108 & 21 & 129 \\
\hline 南標葉 & & 42 & 53 & 54 & 42 & 150 & & 150 & 30 & 180 \\
\hline 山 中 & 郷 & & & & & 129 & 210 & 116 & 2 & 118 \\
\hline 合 & 計 & 338 & 341 & 351 & 338 & 1,555 & & 1,537 & & 1,980 \\
\hline $\begin{array}{l}\text { 府下居 } \\
1 \text { 户当 }\end{array}$ & $\begin{array}{l}\text { 住 } \\
\text { 耕地 }\end{array}$ & $\begin{array}{r}141 \\
\frac{141}{14} \\
14.95\end{array}$ & $\begin{array}{c}216 \\
\text { 石 } \\
13.2\end{array}$ & & & & & & & \\
\hline
\end{tabular}

14）相馬藩政史 昭和 16 年（断りない資料は同書による）。

15）中村市岩崎敏夫氏所蔵. 


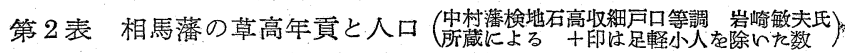

\begin{tabular}{|c|c|c|c|c|c|c|c|c|c|}
\hline & & 草 高 & 年貢米 & 家 中 & 古給人 & 中切給人 & 郷 士 & 足軽小人 & 総：計 \\
\hline 永祿 2 年 & (1559) & 60,428 & & 710 & & & & 3,950 & $4,660^{\circ}$ \\
\hline 鹿長 7 年 & (1602) & （大正18年 & F 48,732$)$ & 212 & 880 & & & & $+1,092$ \\
\hline 元和 3 年 & (1617) & $\begin{array}{l}(8 \text { 年) } \\
60,000\end{array}$ & & 141 & 341 & & & & +482 \\
\hline 筧永16年 & (1639) & 93,251 & & 216 & 351 & & & & +567 \\
\hline (琞糜 4 年 & (1658) & 93,855 & $\begin{array}{l}149,000 \\
\text { (4 壮俵でに }\end{array}$ & $\begin{array}{c}253 \\
\text { は } 119,200)\end{array}$ & 338 & 583 & & 681 & 1,855 \\
\hline 延宝 2 年 & (1674) & 150,024 & & - & & & 622 & & 1,825 \\
\hline 天和元年 & (1681) & 150,024 & (11年) & 478 & 1,126 & & & & $+1,604$ \\
\hline 元祿10年 & (1697) & $\begin{array}{l}137,044 \\
(2 \text { 年) }\end{array}$ & $\begin{array}{l}131,200 \\
(5 \text { 年) }\end{array}$ & & & & & & \\
\hline 正徳 4 年 & (1714) & 98,413 & 175,900 & 360 & 301 & 775 & 622 & & 2,058 \\
\hline 享保14年 & (1729) & & $\begin{array}{l}\text { (延享元年) } \\
140,700\end{array}$ & 5,674 & $13,756^{\circ}$ & & 3,938 & & 23,368 \\
\hline 寬延 3 年 & (1750) & & 134,300 & & & & & & \\
\hline 宝暦11年 & (1761) & $c$ & 116,700 & & & & & & \\
\hline 明和 5 年 & (1768) & $\begin{array}{l}89,8763, \\
(6 \text { 年) }\end{array}$ & 101,879 & & & & & & \\
\hline 安永 9 年 & (1780) & 89,913 & & 642 & 301 & 775 & 310 & 682 & 2,878 \\
\hline 天明 3 年 & (1783) & & 20,300 & & & & & & \\
\hline "I 6 年 & (1786) & & 35,900 & & & & & & \\
\hline 寛政10年 & (1798) & & 74,975 & & & & & & \\
\hline 交化元年 & (1804) & & 72,000 & & & & & & \\
\hline $\begin{array}{r}\prime \prime 13 \text { 年 } \\
\text { 交政元年 }\end{array}$ & $\begin{array}{l}(1816) \\
(1818)\end{array}$ & & & 543 & & & 310 & 469 & 2,413 \\
\hline "I 11年 & (1828) & & 60,300 & & & & & & \\
\hline 天保 5 年 & (1834) & 98,113 & 69,500 & & & & & & \\
\hline 弘化元年 & (1844) & & 78,309 & & & & & & \\
\hline 交久 2 年 & (1862) & 98,900 & & 389 & & 537 & 310 & 不明 & $+2,290$ \\
\hline 鹿応元年 & (1865) & & & （扶持人 114 ) & & 530 & 310 & 527 & 2,516 \\
\hline 明治 3 年 & (1870). & & 91,865 & 411 & & 705 & 316 & 493 & 2,225 \\
\hline $\begin{array}{l}\text { 明治10年 } \\
\text { 金源公債 } \\
\text { 受領の際 }\end{array}$ & (1877) & & & 443 & & 537 & 870 & 570 & 2,957 \\
\hline
\end{tabular}

両の収大から 5 両 2 歩を取立てられては, 奉行出来難いので増徽を免除し てくれるか，さもなければ永の睱を賜わりたいと，在郷居住の武士が 583 名連署して強訴したので，藩は強訴署名者全部の余地を没収し，領内に留 まつて百姓となるか，他領に去るか自由ならしめ，351 名の不乗者の内疑 しい者は減封の上，郷村に残した。中には浪人となつて相馬を去つた者も あろらが大部分が百姓として残つたらしい.

慶安 3 年 (1651) に足軽隊が新たに募集され16)，黒木村に長栖組 150 名， 16）中村藩士族録、昭和 12 年，中村市 岩崎敏夫氏所蔵. 
明暦 3 年 (1657) には，今田と呯田村鶴谷

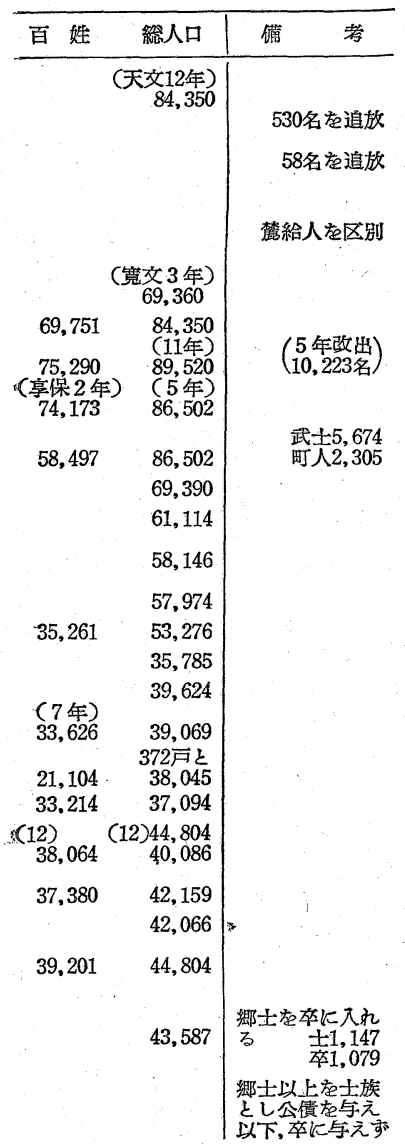
に53 名ずつ, 赤木・初野・石上・小池・ 塩崎・高平に各 52 名ずつ，合計では 598 名の足軽隊が配置された. その後, 延宝 2 年 (1674) 保原街道の玉野に24戸の足軽 隊が設けられたので，総計 622 人となつて いる. 今田・石上・赤木・黒木は中村を中 心とした 4 籸内外の場所にあたり，小池・ 塩崎・鶴谷・高平は原町を中心として配置 されているが，仙台藩の三郷足軽部落や山 形城下の小白川, 米沢郊外の館山・花沢 南原五ケ町, 芳泉町等の街村, または格子 型に規則正しく配置され下級武士の集落と 異なり，足軽だけを線状に配列したのでは なかつた．既存の農家から採用したものか， 新たに希望者を集めて屋敷割して居住させ たのか明らかでなく，百姓と入り混つて屋 敷取りしている集落が多く，規則的にでき ている部分も少ない。

追放された武士の大部分は退散せず, そのまま農民として残つたらしく，復帰 運動を試みる者があつたとみえ，万治元 年, 由緒ある武士の子孫で新しく開墾した 田地を所持する者に禄を与え, 新知給人と して復活させることになつたが，その数は 583 名を数えている. その後孔寬文元年よ り開発次第䈉入を執行したので 6 年, 8 年, 11 年までの検地に際して復活 させたので, その間に給禄の証を得た者の総数 800 名となり, 寛文 8 年 (1668) 以前の古給人と呼ばれるものと, 新知給人の合計が 1,126 名とな つている.

新知給人は新開地を所持する由緒正しい者に限つて許可されたが，農業 附属地迴りの農民の草杊場や薪炭林が狭められ迷惑甚しかつたので, 農民 の不平ついに, 寬文 8 年 3 月一揆を起すに至つた, 藩はその後給人の開墾 


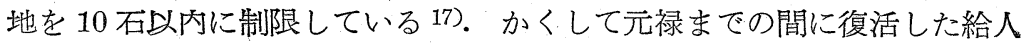
は新知給人または中切給人と呼ばれ，正德以後 1 石につき 5 画ずつ献金し て給人に採用された良士と区別された。もつともこれ以前の中切給人も新 規に採用される際は，若干の献金をしている．しかし，正德以後採用され た郷士は献金を主たる目的として行われたのであるが，正徳 7 年 (1667) の郷士希望者は 79 の寺社を含み 389 名に達し, 献金高は 8,310 両となり, 1,662 石開かれた。この中に は「天明以降農夫商人等金献 為給人鄉士準治府士者多」と 相馬藩政史に見えるごとく給 人とは家格を異にする者が多 かつたので，文化元年から正 月の御目見も給人と鄉士の日

第 3 表 年貢米徴収高

\begin{tabular}{|c|c|}
\hline 期 & $\begin{array}{l}\text { 平均 } 1 \text { 万年の年 } \\
\text { 䆬徵収高 (俵) } \\
\end{array}$ \\
\hline 寛文 5 年〜享保 9 年 (60年間) & 140,079 \\
\hline 享保10年～宝暦 4 年 (30年閒) & 134,674 \\
\hline 宝暦 5 年〜天明 4 年 (30年間) & 101,453 \\
\hline 天明 5 年〜天保15年 (60年間) & 63,793 \\
\hline
\end{tabular}

取りが改められた。 また給人は絹羽織を許され，組頭氏代を命ぜられるこ とになつた．鄉士から命ぜられる場合は勤中のみ同格とせられたのである.

享保 15 年にり在鄉給人鄉士の知行切替があつたがこの時は切替高 1 石 につき 2 两山林 1 両であつた。このように次第に給人鄉士の知行が切替ら れ，更に場所替が献金で可能となつて次第に裕福な給人は便利な土地を耕 作するようになつたので，薪孷林を奪われ草刈場を失つた農民の生活が圧 迫され，寛文 5 年から以降の年貢取立高が 14 万石から次第に減少するよう になつた. 天明 5 年から天保 15 年までの平均が 6.3 万石と半分以下に減 少しているのである. 正徳 2 年 4,709 石の改出も実際には年貢徴収高に影 響せず，却つて減少を示している. 文政 13 年 (1830) 郡代の草野・池田の 両人が藩政改革の必要を論じた中に「我藩は元禄の繩大に民の利を計らず， 収斂を事とした結果，一旦荒来るや急に荒廃するに至つた」と論じている のである. 元禄 5 年の改出 10,223 石となつているのを指しているのであ る. 正德 5 年 (1715) の年貢は 175,900 俵で, 元禄 11 年 (1698) の 131,200 , 俵より多くなつているが，人口はすでに 89,000 より 86,000 にさがり，そ の後は次第に減少し，天明 6 年（1786）のごとさは凶作の影響からでもあ

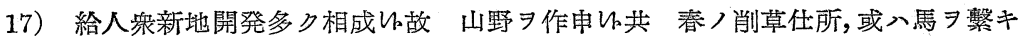
稲 $\exists$ 千場所無之 迷惑致以。电立, 依テ是 $\exists \boldsymbol{y}$ 給人新地開発八高十石限》被仰付, 百姓八別二御然無之（下略） 
るが, 35,700 と元禄時代の半分以下に減少している18).

天和元年（1681）には家中と給人の合計が総戸数の $16 \%$ \%あつたが， 享保 14 年（1729）には $27 \%$ て，明治 5 年（1872）には家中と給人の合計 だけでも明治 3 年の戸数の $25 \%$ となり，足軽小人を加えた数は $30 \%$ 強と なつている.

農家の 1 戸当りの耕地面積は元和元年（1615） 1 町 1 反 4 畧であつたが， 元禄 10 年には 9 反 8 粢 28 歩となつている. 耕地の減少によるものでなく, 農家戸数の増加に基ずくのであるが，享保 2 年(1717)にも大差なく 9 反 8 畧 23 歩であつた。天保 5 年 (1834) には田畑の面積が半分以下の 6,888 町 歩となり,農家戸数は 7,251 戸に減少し, 享保時代の半分以下になつている。 しかし耕地も減つているので 1 戸当りの耕地は 9 反 4 䇉 25 歩となつてい る. 耕地の減少が農家の減少に関連しているのであろう. 藩の財政は年貢 の減少で益々急迫してきたし寛政 9 年(1797)には元来高外の原野を開墾し たゆえ地味の良くない土地を知行地としていた給人郷士に呼びかけ19)，金 殻を上納させて新に知行地を与え，あるいは「切継・切替・片付地へ被相済， 他郷他村の知行荒地を上げ付寄之良田切替開墾被相済」とて知行地の増加 を許し，あるいは交換を認めたそそのため上納高は一層減少するのである. 文化 11 年には在郷給人鄉士階級引上御知行荒地を片付地に切替 1 人に つき 1 石分ずつの割合で開拓させ, 10 年間米 1 俵半ずつ上納させることに したが，荒地を所持してない者には代地を命じ 10 ケ年間 1 俵ずつ上納さ せるという処置をしたので鄉士給人の困難が甚しかつた。しかし中には良 田を荒廃地と切替え私利を図るものも少くなかつたらしい.

藩は一方ではこのように給人鄉士より金米を納入させるとともに人口の

18）天明の凶作は特に相馬藩の人口を減少させた 3 年 $(1783)$ の春に 48,244 人居 つたのが，翌年の 3 月には欠落 1,843 人，死亡 4,416 人も出たので 44,416 人と なり，空屋敷が 1,371 戸もできている，減少したのは農家のみでなく，郷士も 400 戸位あつたと云う。
19) 1. 13両
新知片付地
1 石に付
1. 6 両
切継片付地
1. 3 两 2 分
切替片付地
1. 2 両
切替片付地
1. 10 両
新地荒地
1. 5 両
切継荒地
1. 2 両 2 分 切替荒地
（ただし生地を上げて切替）
"
（たたし生地を上げて淂）
（ただし荒地を上げて切替） 
增殖を図らざるを得ない立場となり，寛政元年(1789)頃から，積極的に人 口の增殖策に乗り出している，すなわち他領農民の移入を歓迎し，富農ま たは裕福な鄉士，給人等に新百姓の育成に骨折らせ，藩費を投じて直接間 接に援助を与えているのである・上杉藩でも治憲公は人口増殖にすこぶる 骨折つているが，相馬藩の育成した天保 4 年の御頼建百姓と呼ばれる百姓 は 55 戸，金立建百姓と呼ばれる金立の投資による新百姓 123 戸で，1,038 人が取立てられ，929石の新田が出来ているのである.この間に投ぜられ た藩費は 811 両で，金主その他の投資を合せて 31,873 両 2 歩 2 朱である. また天保 6 年の 新軒取立の入費は 4,589 両 3 歩となつているが，この内 3,271 両 3 分 1 朱と米 6,079 俵が藩の支出であつた. 寬政元年（1789）よ り文化 13 年 (1816) までの間に 188 戸，文化 14 年（1817）より弘化 4 年 （1847）までの間に 1,974戸を入植させているが，藩費による者 7,804人， 金主立による者 1,139 人で，この内には加賀・越後・最上等の入植者が 1,678戸もあつた. 安政 4 年 39 町 53 䇉 23 歩，草高 259 石の開発ができ たが 50 軒の内越後者 14 戸，加賀 27 戸，越前 3 戸，仙台・岩城・米沢・ 最上・関東各 1 戸ずつ入つている.もつぱら他国の入植者で完成したわけ である. その後もこの計画は継続され 1 戸 10 両と米 10 俵を給与されたの で，明治 4 年までの間に 1,379 町歩の耕地が開かれ，573 戸が定住してい るが，それでも元和時代の 16,517 戸に比較すると，明治 3 年（1870）の 戸数は 7,489 戸20)と半分以下に過ぎなかつた.

相馬藩では「古は皆地方にて給与し, 皆三郡内の鄉村に在住し, 其の大 なる者は館持と称し村邑に豪居し, 多少の武夫並に百姓を有ち小なる者は 秩禄の田畑を自作し以て給禄に代うるを法とす」（相馬藩政史）とあるご とくで，館持が城下に集められた後も古給人が領内各地に散点していたの に, 中切給人が追加されたので，ほとんど各部落に給人鄉士が混住してい

20）弘化 2 年から二宮翁の指導に基ずく御仕法が実行されているのである．岩崎 敏夫，相馬の二宫仕法，昭和 30 年.

21）侍家作定 3 間梁，行間 9 間，100 石以下四脚門無用，1,000 石以下表長屋無用， 折目縁 400 石以下無用.

郷士給人家作 3 間梁 行間 7 間限, 裹板は座敷限, 書院玄関無用.

足軽家作 3 間梁 行間 3 間限.

百姓 士分と家作を同うする事を得ず，門塀を構える事を得ず，百姓は土分及村 役人と同座する事を得ず. 
た.したがつて楖士と百姓との区別がやかましかつた。百姓は門や塀を構 えることを禁ぜられているのみならず，家屋も制限され，一目して区別で きるようにさせられた，武家に対する百姓の上訴が禁ぜられていたことが， 恐らく混住生活を続けた農民に苦痛であつたらしい，追放武士の子孫が鄉 士に復活しているのは，そのような差別的生活に不満を感じていた故であ ろう.

部落ごとに居住する給人鄉士は，部落の有力者として人民を支配する立 場にあつたらしく，赤木の太田家も，しばしば村目付役とか肝煎等の役に ついている23).

江戸時代には禄高の売買は当然禁ぜられていたわけであるが，同家の記 録によると売買も認められ，それによると知行高の増減もあつた23)。中世 の遗制であろう.

太田家は屋敷林に囲まれ，背後に広い耕地を持ち，ほぼ 1,000 坪ほどの 屋敷に居住しているが，荒川太郎右衛門家の旧記に「荒川屋敷四方 30 間 程，四方堀は，三間程」と見えるように，米沢盆地の豪族屋敷に比較出来

22）同家の系図書・由緒書等によると，同家は井上兵部と称し 奥州行方郡太田里 に流れ付いた浪人で，元亨 3 年（1323）功相馬家に仕え，文緑 2 年（1593）に は小高に打いて 1 貫 163 文の知行を与えられ，子の宗久は 30 石に昇進した：徒 つて城下移駐を命ぜられるはずであつたが 28 石以下であると称して小高に止ま つた. 元和 3 年 (1617) の強訴に加わつたので浪人となり, 禄を失つたので宇田 郷稲田村に落付き 100 石程の新田を開いて農耕を営んでいたが義絸公の時再び給 人となり，50石を開いて赤木村に移つた. 寛永 16 年（1639）の検地に 29 石と記 録されているから間もなく復活したものらしく，6代の間手代をつとめあるいは 村目付をたは肝煎となり，製塩業や網等に投資し，あるいは金貸業を営み頗る富 裕であつた（太田慈宗氏所蔵記録による）. 藩の方針で新百姓を㕕成することに なつたので，文政 3 年 (1820) から協力することにした， 4 軒を自費で 23 軒を抨 借で仕立て，申年 [7 年(1824)]までの閒に 169 石を開き，他所者で確実なる者 16 人を家抱えとして取立て，その功を賞せられている.

安政 3 年（1856）の太田宗右衛門百姓割には，7人の百姓に 60 石を割付け耕 作させているから，地主的性格を兼ねていたことが明らかである.これらの手柄 から三代御城下並となり，2石の切継加増を許されている.

23）当凶荒に付，国民為御救金式両式朱上納仕候二付，御賞与茂可有之処，北 屋形村今野半次郎知行之内，四石五斗三升壳合壱勺，立谷村荒仲次郎知行之内， 武石六升四合五勺，同村馬場万右衛門御知行之内，三斗六升九合三勺，合六石九 斗六升四合九譲請, 同人御知行之内, 壱石三斗四升式合六勺取替地双方熟語之 上，願之通被仰候也天保六酉年 三月 
るような堂々たる給人屋敷もあつたことがわかるが，一般に相馬に現存す る 301 人の古給人屋敷には案外立派なものが少ない.

しかし旧屋敷と思われる土地に，堀形が残つているものもあるし，また 近所に古館跡が見られるものもあつたから，古い時代には館に居住した土 豪が多く，それぞれの部落を支配したものらしいが，28 石以上の者を城下 に集めた折，館主級の者は大部分城下に移つて，蔵米の配分を受ける知行 取りとなり，給人は館から出てしまい，荒川家・太田家のごとき特例が所 々に残つたものらしい. 明治初年（1868）の 1 町以上の耕地の買上げに応 じた者が多いと伝えられるから，この時耕地の大部分を失つて，生活が平 均化したらしく，古給人も中切給人にも，ともに土豪的生活を続けて来た と見えるのは大して多くない.

明治維新の後 443 戸の城下居住の，いわゆる家中衆に土地を与えて鹵農 させる政策が，実施されることになつた. 1 町歩以上の所持者から余分の 土地として，水田は反 15 円，畑はその半額で買収し，1 戸当り 1 反歩の 畑を含んで 9 反ずつ分与し，城下中村に土着する者には，田 7 反歩と畑 3 反を与えることになり，341 町 7 反 7 畧 29 歩の田地が 54,700 両余で買収 した。このような政策がともかくも，強行されたことは驚くべきである.

鹵農者には従前から所持していた抱地のあつた者が 11 軒あつたので, それには 5 両ずつ, 従来からの抱地を持ち城下に住みついた者 2 名に 20 両, 城下に罩引で居住を定めた 17 軒の者に 25 両ずつ，その中で転住した者 25 軒に 30 両ずつ，従来からの抱地を持つていたのでそこに転居した者 4 軒 に 55 両，闇引で郷村に移住した者 382 名に 65 両ずつ与えた。すなわち大 部分が無縁故地に分散したわけである.

317 町 4 畧 18 歩の田畑を百姓より購大するに 23,778 両を要し， 341 町 7 反 7 畧 29 歩と 64 町 3 反 5 畧 22 歩の購入に 5,470 両を要したが，田 15 町 7 反 6 䇉と烟 48 町 5 反 9 欯 22 歩は, 中村在住士族抱地や士族屋敷跡ま たは潰百姓散田等で，地代金を要しなかつた。このほか 1,020 両は 8 反未 満しか当らなかつた者に 1 反 15 両ずつを与えて, 6 町 8 反歩を開かせるに 要した費用で， 672 両は田地不足の者に渡した畑にすべき 17 町 9 反 3 畧 12 歩の開墾費であつた.

このほか，土着手当金として支給した費用が 26,365 両を要したのであ つたが，51,835 両は旧知事在職中の手当金として交付したものであり，3 万両は土族に与えられる士族永禄を担保にして，古川市兵衛よりの借大金 
3,000 両は，管内士族の無尽備米 3,000 俵を献納したものであつた. 田地 の買取は希望によつて行われたと伝えられるが，ほぼ均等に各地に家中を 分配配置したものを見ると計画的に買入れているのであろう.

明治初年の農村移住政策は武士の土着を助け，散逸を防いだのであるが， 一旦土着しても再び城下に舞い戻つた者も少なくないし，流転したものも 多く箯者等の実地調査した範团では土着して現存するものは $1 / 3$ 位らしい. 弘前潧でも同じような政策が行われたが，ここでは 10 町以上所持する者 からそれ以上の持高を提供させ，帰農武士にその地主的支配に当らせたの であつた。この方は一層残存率が少ないように思われた.いずれも農村に 根を下したのでないから，失敗した者が多かつたわけであるが，古給人や 中切給人, 郷士には転退した者が極く少なく, 名簿を辿つて村ヶを迴るこ とができた。しかし系図と由緒書の外の古記録を所持する者がほとんど無 かつたので，記録による調査は予期した程，成果が挙らなかつた. 小さい 藩であるから，所々に設けてあつた代官所で，記録を取扱つていた関係ら しい.しかし中世以来続いた古給人が農村に土着して今日に至つている事， しかも直接旰煎等の村役を勤めて農民を支配していた事実を知る事ができ た。

(以下次号)

\section{台湾の地理区域}

\section{陳正 祥}

中国の全部の省区域のうち，台湾省の面積は一番小さいが，その自然と 人文を含んだ地理現象は極めて複雑である.台湾の地理の複雑性は主に特 殊な地勢によつて形づくられた．台湾省の土地面積は僅かに約 $35,960 \mathrm{~km}^{2}$. しかし台湾中東部の綿延たる山嶺は, 平均高度 $3,000 \mathrm{~m}$ を超えている. 大 武山と次高山の間に高峯二十余個もあり, その高度すべて $3,500 \mathrm{~m}$ を超過, 最高の玉山（新高山）は高さ $3,950 \mathrm{~m}$ にも達している.これは中国東南各 省の中でも特殊な現象であるが，全世界的にいつても，こんな小島にかく のごとき高山があるのは実に稀であろう.

台湾は山区が中東部に偏在しているため, 僅か西部に 1 つの比較的広濶 な平原があるのみ.山区の周辺には連続している丘陵地帯あり，丘陵の間 に局部的盆地と扇状地が若干ある. 地図による筆者の測量結果によれば, 